\title{
Polygynous Family Structure and Child Undernutrition in Nigeria
}

Mulubrhan Amare, Channing Arndt, Kristi Mahrt, and George Mavrotas 


\section{CONTENTS}

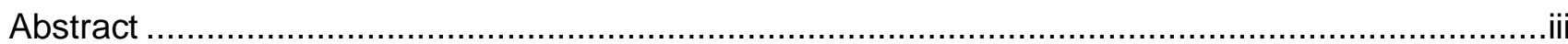

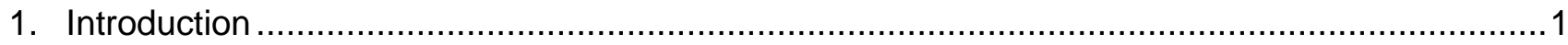

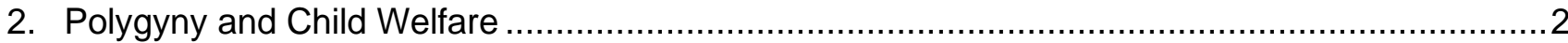

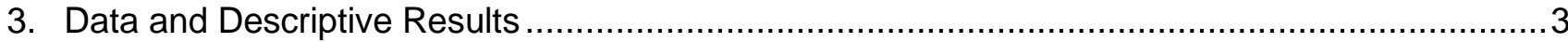

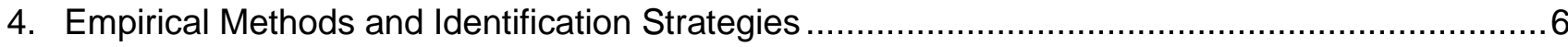

5. Empirical Results on Impacts of Polygyny on Child Nutritional Outcomes ...............................8

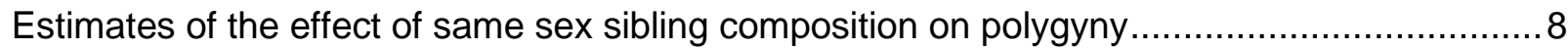

Instrumental variable estimates of child undernutrition.................................................. 11

Heterogeneous impact of polygyny on child undernutrition by wealth status and level of

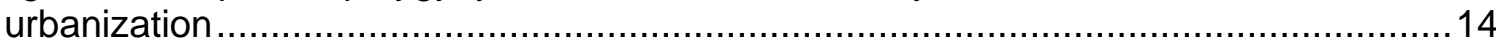

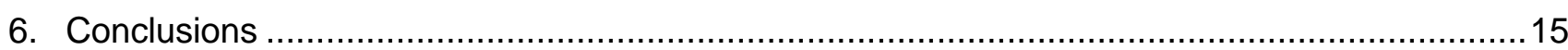

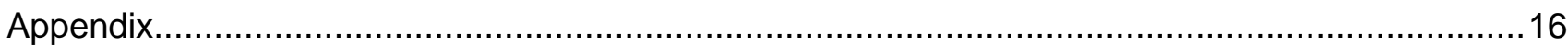

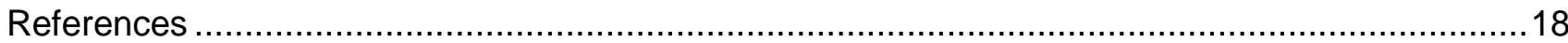

\section{TABLES}

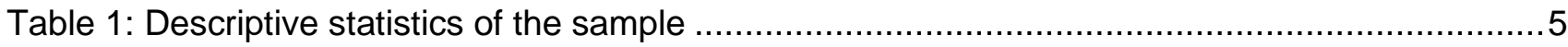

Table 2: Men's preferences for balanced sibling sex composition, by area ................................. 7

Table 3. Effect of the presence of same sex siblings on polygyny outcomes .............................. 9

Table 4: Effect of parental characteristics on the presence of same sex siblings .........................10

Table 5: Ordinary Least Squares and Instrumental Variable estimates of the effect of polygyny on child height-for-age z-scores

Table 6: Ordinary Least Squares and Instrumental Variable estimates of the effect of polygyny on child stunting rates

Table 7: Instrumental Variable estimates of the effect of polygyny on child height-for age z-score

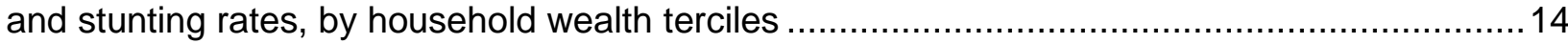

Table 8: Instrumental Variable estimates of the effect of polygyny on child height-for age z-score and stunting rates, by level of urbanization categories .................................................. 14

Table A1: Effect of same sex siblings on child height-for age z-score and stunting rates .............. 16

Table A2: Estimates of relationship between child height-for age z-score and stunting and the presence of same sex siblings born to monogamous women.

\section{FIGURES}

Figure 1: Cumulative density function of child height-for-age z-score for polygynous and non-polygynous households 


\section{ABSTRACT}

There is a growing interest in the research literature in exploring how child nutrition is affected by sociocultural practices, such as polygyny. However, evaluation of the effect of polygyny on child nutrition has been hindered by the complexity of the relationship. This paper investigates the effect of polygyny on anthropometric outcomes while recognizing that unobservable household characteristics may simultaneously influence both the decision to form a polygynous union and the ability of the household to adequately nourish children. Polygyny can affect children's nutrition through increased family size, early marriage, and the level of household investment in child health. In this paper, we apply an instrumental variable approach based on the occurrence of same sex siblings in a woman's first two births to generate exogenous variation in polygyny. Using data from the 2008 and 2013 Nigeria Demographic and Health Surveys, we find a detrimental effect of polygyny on child undernutrition, with a greater effect in poorer households and those resident in more urban locations.

Keywords: child gender composition, polygyny, child undernutrition, Nigeria JEL Classification: C81 D63 I15 J12 J13 O12 


\section{INTRODUCTION}

Undernutrition continues to be a major challenge and cause of under-development in low- and middle-income countries. Undernutrition in sub-Saharan Africa in particular remains pervasive due to insufficient food intake, widespread micronutrient deficiencies, and health challenges, including a significant disease burden and the adverse public health impacts of poor water and sanitation facilities. Across sub-Saharan Africa, one-third of children under five years of age are stunted in their growth and 8.5 percent are acutely undernourished (WHO 2017). Undernutrition imposes high social and economic burdens which amount to between 3 and 16 percent of GDP annually (Global Panel 2016). A lack of substantial gains in reducing undernutrition may necessitate looking beyond socioeconomic factors to sociocultural dimensions to explain the drivers of undernutrition in children.

A growing interest is evident in the research literature to explore how child undernutrition is affected by social and cultural practices, such as polygyny (Smith-Greenaway and Trinitapoli 2014; Gyimah 2009; Westoff 2003). ${ }^{1}$ The focus of this paper is on associations between polygyny and child undernutrition in Nigeria, the most populous country in Africa with a rapidly growing population that stood at about 200 million in 2017. One-third of Nigerian women are in polygynous unions, a level which has remained steady over time (NPC and ICF Macro 2009; NPC and ICF International 2014). As is the trend throughout sub-Saharan Africa, Nigeria has made gains, if slow, in reducing child undernutrition in recent years. However, undernutrition remains high. In 2013, it was estimated that one out of three young children were stunted in their growth, a reduction from the 42 percent of children estimated to be stunted in 2008 (NPC and ICF Macro 2009, NPC \& ICF International 2014). ${ }^{2}$ Moreover, while undernutrition is prevalent throughout the country, significant heterogeneity is seen across geo-political zones - levels of child undernutrition are significantly higher in northern Nigeria.

While research on the relationship between polygynous family structure and child undernutrition is growing (e.g., Wagner and Rieger 2015; Gyimah 2009; Westoff 2003), less is known about the effect of polygyny on child undernutrition because of the complexity of the relationships. The same factors that affect child undernutrition may also affect decisions on family structure. This makes estimating cause-to-effect relationships between polygyny and child undernutrition complicated. While we are treating polygyny as causal, it is not actually polygyny that causes undernutrition. Polygyny can affect children's nutrition through several mechanisms. It can affect children's nutrition through low parental education attainment, increased family size, encouraging early marriage, and reduced household investments in child health. We control for some of these possible mechanisms.

To the best of our knowledge, this is the first study to tackle the issue of identifying the effect of family structure on child undernutrition by using an instrumental variable approach. Building on previous studies (e.g., Conley 2000; Black et al. 2005; Conley and Glaube 2006; Angrist and Evans 1998), we instrument polygyny with the sex of the first two births to the first wife in a household, specifically same sex first and second born children, i.e., only sons [boy-boy] or only daughters [girlgirl]. We base this choice of instrument on evidence indicating a preference in Nigeria for families composed of children of both sexes. When the first two births result in same sex siblings, the desire for mixed sex composition may trigger polygyny, which provides exogenous variation. Using this analytical approach, we explore the effect of the polygynous family structure on child undernutrition in Nigeria. In Nigeria, as in much of West Africa, significant life choices, such as fertility and childcare decisions, are influenced by numerous cultural beliefs and practices (Briones Alonso et al.

\footnotetext{
${ }^{1}$ Polygyny, the practice of one man being married to multiple wives at the same time, is a common family structure in many parts of subSaharan Africa.

2 In contrast, other highly populated countries have witnessed considerable declines in child undernutrition (Headey 2013). For example, Bangladesh has managed to reduce its stunting prevalence from 51 percent in 2004 to 36 percent in 2014
} 
2018; Arthi and Fenske 2018). The combination of both widespread polygyny and widespread child undernutrition makes Nigeria a particularly relevant environment for assessing this relationship to elucidate appropriate policy responses to reduce child undernutrition. This paper principally uses the 2008 and 2013 Nigeria Demographic and Health Surveys (NDHS) to assess this complex relationship. Both surveys contain information on child anthropometric outcomes and the polygyny status of women, which make them well suited for this analysis.

The effect of polygyny on child nutritional outcomes likely varies by household wealth and place of residence. Therefore, we also examine whether the effect of polygyny varies with household wealth status and level of urbanization in the community of residence of the household to understand which children in which households are affected most. Our measure of wealth is based on household assets recorded in the NDHS surveys (Rutstein and Johnson 2004). Our measure of urbanization is constructed using nightlight satellite data judged to be a valid marker of urbanization and urban settlements (Imhoff et al. 1997; Sutton 1997; Storeygard 2016; Henderson et al. 2003; Sutton et al. 2010; Amare et al. 2018).

We find a detrimental effect of polygyny on child undernutrition, with a greater effect in poorer households and those resident in more urban locations. The estimates on the effect of polygyny are substantially reduced when we control for household and child characteristics and wealth indicators, suggesting, as expected, that part of the link between polygyny and child undernutrition is mediated through these channels. Nevertheless, the estimated coefficients on polygyny remain sizeable and strongly statistically significant even after controlling for these characteristics. This analysis does not provide clear insights as to what accounts for this link. The possibilities of childcare practices that vary from those in monogamous households and of reduced bargaining power for women in polygynous households could be associated with higher rates of child undernutrition. However, we could not control for such factors in our analysis.

The paper is organized as follows. Section 2 presents the conceptual framework on direct and indirect interactions and linkages between polygyny and undernutrition in children. Section 3 presents the data and key variables used in the empirical analysis. Section 4 presents the empirical model and the identification strategy. The results are presented in Section 5 before we conclude in the final section, highlighting the main findings and tentative policy implications.

\section{POLYGYNY AND CHILD WELFARE}

The literature provides numerous explanations for the practice of polygyny in Africa, including increased labor supply from multiple wives in agrarian societies; men's wealth and power; and the child-rearing capability of the first wife (Boserup 1970; Ezeh 1997). In certain tropical regions, some societies have post-partum sex taboos, which forbid a married woman from sexual activities for up two years after her child is born to ensure good lactation and healthy child development (Caldwell and Caldwell 1987). During these periods, wives consent to share their husbands with another wife to deter the husband from engaging in sexual relations outside the family. In combination with early marriage, the polygynous marriage system has helped maintain high fertility rates of between 6 and 8 children per family in many African countries (Caldwell and Caldwell 1987; Arthi and Fenske 2016; Fenske 2015). In some cultures, large family size and polygyny is attributed to a higher social ranking (Ezeh 1997), hence, it is desirable for a man to have multiple wives and to marry early if he desires to have a large family.

There is a growing interest in the research literature to explore how child nutritional outcomes are affected by social and cultural practices, such as polygyny (Smith-Greenaway and Trinitapoli 2014; Arthi and Fenske 2018; Munro et al. forthcoming; Strassmann 2011). However, the relationship between polygyny and child growth has not been conclusive. Some literature suggests 
that the presence of multiple wives in the household could enhance child welfare (e.g., Ukwuani et al. 2002; Akresh et al. 2016), demonstrating that children in polygynous families could have the advantage of more frequent care and supervision by adults than those in monogamous families (Akresh et al. 2016). Polygyny may delay the resumption of or reduces the frequency of intercourse after childbirth, which improves outcomes by improving breastfeeding practices and child spacing (Ukwuani et al. 2002).

Although these studies showed the possibility of positive contributions of polygyny to child development, a large body of research has documented a detrimental association with child growth and survival (e.g., Smith-Greenaway and Trinitapoli 2014; Hadley 2005; Sellen 1999; Wagner and Rieger 2015; Arthi and Fenske 2018). Smith-Greenaway and Trinitapoli (2014) review theories as to why polygyny may be associated with poor child outcomes, specifically increased child mortality. They argue this association might occur both due to the characteristics of environments that are more conducive to polygyny and to characteristics of polygynous families.

Polygyny could influence child nutritional outcomes through different channels.

- Polygyny is associated with large family size and characterized by many young children from different wives of similar age. Consequently, children may compete for nutritional and financial resources and parental time, which adversely affects nutritional outcomes, especially in resource-poor environments (Basu 2000; Strassmann 2011; Arthi and Fenske 2018; Milazzo 2018). ${ }^{3}$

- The poor nutritional and health status of children in polygynous families could be associated with gender discrimination and low parental education attainment (Mammen 2009). This is both because less educated parents have limited exposure to nutrition information and have limited skills to recognize, process, and apply the nutrition and health knowledge they have acquired. As a result, parents with low education levels are less able to improve their own nutritional status and that of their families (Behrman and Rosenzweig 2002; Plug 2004). ${ }^{4}$

- The polygynous family structure encourages early marriage. Not only do girls who marry young experience higher rates of malnutrition, isolation, and depression, there is also a longterm impact on child growth (Le Strat, Dubertret, and Le Foll 2011). Children of young mothers are likely to have lower birth weight, suffer poor nutritional status due to poor physical health outcomes, and experience higher rates of infant mortality (Rahman, et al. 2016).

However, even where a relationship between marital choice and child welfare is established, these studies do not attempt to evaluate whether polygyny is a causal factor (Wagner and Rieger 2015, 1997; Gyimah 2003; Westoff 2003).

\section{DATA AND DESCRIPTIVE RESULTS}

Our analysis uses individual and household data collected in the 2008 and 2013 Nigeria DHS.

These surveys are well suited for this study because they contain both information on the polygyny status of women who are married and child nutritional outcomes. The surveys capture mother, child, and household information, including socioeconomic characteristics, anthropometric measurements, household assets (wealth index), and demographic information, among others. These are nationally representative surveys covering both urban and rural households.

\footnotetext{
${ }^{3}$ Lower resource levels are associated with lower expenditures on food and nutrition-relevant non-food expenditures, such as health, sanitation, electricity, water, and housing quality, which can deteriorate the nutritional status of children (Omariba and Boyle 2007).

${ }^{4}$ Less educated parents may also achieve less diverse income due to limited labor market participation. A more diverse set of income sources could help to improve the nutritional status of children.
} 
The unit of analysis for this study is children under five years of age whose mothers are married and have had at least two surviving births. The final combined sample is comprised of 13,935 children from the 2008 survey and 18,058 children from the 2013 survey.

The DHS data provide information latitude and longitude locational data for each survey cluster, which enables merging night-time light data from the Operational Linescan System (OLS) sensors of the Defense Meteorological Satellite Program (DMSP) of the United States Air Force. Various studies have shown that satellite-based night-time light intensity is a valid continuous measure of urbanization and urban settlements (Imhoff et al. 1997; Sutton 1997; Henderson et al. 2012; Storeygard 2016; Amare et al., forthcoming).

Anthropometrics. We measure child growth based on child anthropometry for all children underfive years of age as captured by height-for-age z-scores (HAZ), as well as the prevalence of stunting derived from HAZ. A child is considered stunted if the HAZ for the child is less than -2.0 (two standard deviations below the median measurement for the reference group) (WHO Multicentre Growth Reference Study Group 2006). Stunting in children represents linear growth that has failed to reach genetic potential as a result of a child receiving inadequate nutrition over a sustained period or experiencing recurrent or chronic illness (Black et al. 2013; Hoddinott et al. 2008).

Polygynous family structure. We create a polygyny dummy that takes on a value of one if a child's mother reports having co-wives. The variable is created for women who are married or living with a partner.

Table 1 summarizes outcome variables, family structure measures, and child and parental characteristics. The average values of child HAZ in the pooled sample are -1.46 . The prevalence of child stunting is high at 40 among underfives, although the prevalence of stunting fell from 43 percent in 2008 to 37 percent in 2013. The average age of children in the sample is 29.7 months. The average number of siblings is 4.8 . On average mothers complete fewer years of education than their spouses, 4.6 and 6.2 years, respectively. The average age of mothers at first birth is about 19 years.

We also report outcome variables and child and parental characteristics by family structure. The prevalence of polygyny is quite high in Nigeria. On average, 33 percent of children in our sample live in polygynous families. Children in polygynous families have 33 percent lower HAZ scores than children in monogamous families. Moreover, this difference can be detected across the entire distribution of anthropometric status (Figure 1). Similarly, children in polygynous families are 31 percent more likely to be stunted compared to those in monogamous families. Polygynous families are characterized by a greater number of siblings. Mothers in polygynous unions complete three fewer years of education and give birth earlier than their monogamous counterparts. Although polygynous families are most prevalent in Hausa society - about 46 percent of Hausa women in the sample practice polygyny - the practice exists across all ethnic groups. About 72 percent of children in polygynous families live in areas with zero-night light, compared to half of children in monogamous families. 
Table 1: Descriptive statistics of the sample

\begin{tabular}{|c|c|c|c|c|c|c|c|c|c|}
\hline \multirow[b]{2}{*}{ Variables } & \multirow{2}{*}{\multicolumn{2}{|c|}{ Pooled }} & \multicolumn{2}{|c|}{ Year } & \multicolumn{2}{|c|}{ Family structure } & \multicolumn{3}{|c|}{ Polygynous families } \\
\hline & & & Mean & 2013 & $\begin{array}{c}\text { Non- } \\
\text { poly- } \\
\text { gynous } \\
\text { Mean }\end{array}$ & $\begin{array}{c}\text { Poly- } \\
\text { gynous } \\
\text { Mean }\end{array}$ & $\begin{array}{c}\text { Two } \\
\text { wives } \\
\text { Mean }\end{array}$ & $\begin{array}{l}\text { Three } \\
\text { wives } \\
\text { Mean }\end{array}$ & $\begin{array}{c}\text { Four or } \\
\text { more } \\
\text { wives } \\
\text { Mean }\end{array}$ \\
\hline \multicolumn{10}{|l|}{ Outcome variables } \\
\hline Height-for-age z score (HAZ) & -1.44 & 2.04 & -1.48 & -1.41 & -1.29 & -1.76 & -1.79 & -1.68 & -1.56 \\
\hline Child stunting (HAZ<-2), $0 / 1$ & 0.39 & - & 0.41 & 0.38 & 0.35 & 0.47 & 0.47 & 0.45 & 0.41 \\
\hline \multicolumn{10}{|l|}{ Family structure } \\
\hline Polygynous family, $0 / 1$ & 0.32 & 0.47 & 0.32 & 0.33 & & & & & \\
\hline \multicolumn{10}{|l|}{ Child and parental characteristics } \\
\hline Child is boy, $0 / 1$ & 0.50 & 0.50 & 0.50 & 0.50 & 0.50 & 0.50 & 0.50 & 0.49 & 0.51 \\
\hline Age of child, months & 29.93 & 17.23 & 29.74 & 30.07 & 30.01 & 29.75 & 29.68 & 30.14 & 29.75 \\
\hline Children ever born, number & 4.78 & 2.41 & 4.77 & 4.78 & 4.46 & 5.44 & 5.36 & 5.87 & 5.65 \\
\hline Mother's educational attainment, yrs & 4.69 & 5.16 & 4.80 & 4.61 & 5.76 & 2.45 & 2.42 & 2.38 & 3.42 \\
\hline Spouse's educational attainment, yrs & 6.32 & 5.72 & 6.32 & 6.31 & 7.24 & 4.38 & 4.33 & 4.42 & 5.11 \\
\hline Age of mother at first birth, years & 19.27 & 4.19 & 19.31 & 19.24 & 19.68 & 18.43 & 18.41 & 18.40 & 18.91 \\
\hline \multicolumn{10}{|l|}{ Wealth index quintiles } \\
\hline Poorest quintile, $0 / 1$ & 0.22 & - & 0.21 & 0.23 & 0.19 & 0.30 & 0.31 & 0.25 & 0.10 \\
\hline $2^{\text {nd }}$ quintile, $0 / 1$ & 0.22 & - & 0.22 & 0.22 & 0.19 & 0.28 & 0.28 & 0.27 & 0.23 \\
\hline $3^{\text {rd }}$ quintile, $0 / 1$ & 0.19 & - & 0.20 & 0.19 & 0.19 & 0.20 & 0.19 & 0.23 & 0.29 \\
\hline $4^{\text {th }}$ quintile, $0 / 1$ & 0.19 & - & 0.19 & 0.19 & 0.20 & 0.15 & 0.14 & 0.17 & 0.22 \\
\hline Richest quintile, 0/1 & 0.18 & - & 0.19 & 0.18 & 0.23 & 0.07 & 0.07 & 0.08 & 0.15 \\
\hline \multicolumn{10}{|l|}{ Ethnic group } \\
\hline Yoruba, 0/1 & 0.13 & - & 0.15 & 0.12 & 0.15 & 0.09 & 0.09 & 0.08 & 0.12 \\
\hline Fulani 0/1 & 0.08 & - & 0.07 & 0.08 & 0.07 & 0.11 & 0.11 & 0.10 & 0.03 \\
\hline Hausa, 0/1 & 0.32 & - & 0.29 & 0.35 & 0.25 & 0.46 & 0.47 & 0.46 & 0.32 \\
\hline Igbo, $0 / 1$ & 0.12 & - & 0.13 & 0.11 & 0.16 & 0.03 & 0.03 & 0.04 & 0.10 \\
\hline Other, 0/1 & 0.35 & - & 0.36 & 0.34 & 0.37 & 0.31 & 0.30 & 0.31 & 0.42 \\
\hline \multicolumn{10}{|l|}{ Level of urbanization, night-time lights } \\
\hline $\mathrm{DN}=0$ & 0.57 & - & 0.58 & 0.57 & 0.50 & 0.72 & 0.72 & 0.73 & 0.63 \\
\hline $\mathrm{DN}>0 \& \mathrm{DN} \leqslant 13$ & 0.19 & - & 0.19 & 0.20 & 0.21 & 0.17 & 0.17 & 0.14 & 0.23 \\
\hline $\mathrm{DN}>13 \& \mathrm{DN} \leqslant 48$ & 0.14 & - & 0.15 & 0.13 & 0.17 & 0.08 & 0.08 & 0.08 & 0.10 \\
\hline $\mathrm{DN}>48$ & 0.09 & - & 0.08 & 0.10 & 0.12 & 0.04 & 0.04 & 0.05 & 0.05 \\
\hline \multicolumn{10}{|l|}{ Instruments } \\
\hline Same sex siblings & 0.51 & - & 0.51 & 0.50 & 0.50 & 0.51 & 0.51 & 0.52 & 0.51 \\
\hline Observations & 31 & & 13,935 & 18,058 & 21755 & 10238 & 8,414 & 1,448 & 376 \\
\hline
\end{tabular}

Source: Authors and Nigerian Demographic and Health Survey (NDHS), 2013 and 2008; and NOAA's National Geophysical Data Center. Notes: DN = digital number; values range from 0 to 63 . 
Figure 1: Cumulative density function of child height-for-age z-score for polygynous and non-polygynous households

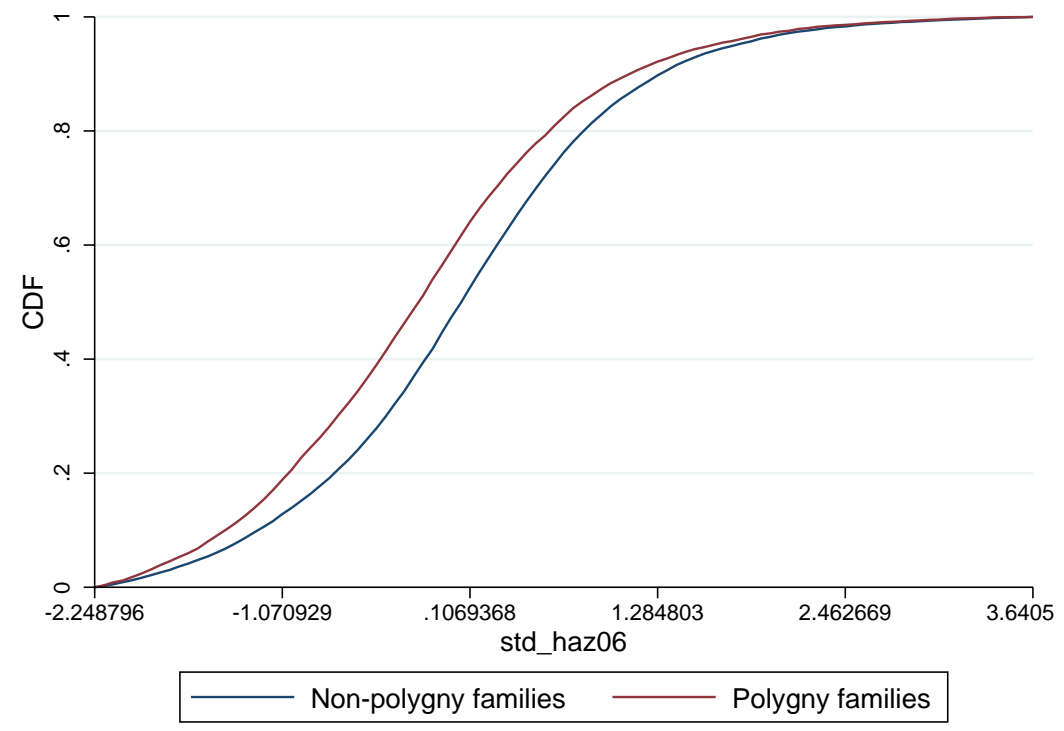

Source: Authors; Nigerian Demographic and Health Survey (NDHS), 2013 and 2008.

\section{EMPIRICAL METHODS AND IDENTIFICATION STRATEGIES}

In this section, we present our empirical approach to estimating the effect of polygyny on child anthropometric measures. We follow previous research to guide our choice of control variables (e.g., Black et al. 2013; Smith et al. 2005). Specifically, we control for the age of the child, number of siblings, mother's educational attainment, mother's age at first birth, spouse's educational attainment, and household wealth status. We control for number of siblings and mother's age at first birth because polygyny is associated with larger household sizes, which is associated with higher risk of stunting (Jayachandran and Pande 2017; Kugler and Kumar 2017; Black et al. 2013; Pande 2003). Polygyny is also associated with early marriage, which is associated with higher rates of malnutrition, isolation, and depression (Le Strat et al. 2011). We also control for household wealth status (Munro et al., forthcoming). ${ }^{5}$

We first estimate the following standard ordinary least squares (OLS) regression for each survey year:

$$
Y_{c h}=\beta_{0}+\beta_{1} \text { polygyny }_{c h}+\beta_{2} X_{c h}+\beta_{3} Z_{c h}+\mu_{v}+\varepsilon_{c h}
$$

where $Y_{c h}$ stands for our anthropometric measures of a child (c) in household (h). Polygyny is denoted by a dummy that takes on a value of one if a child's mother reports her partner to have one or more co-wives. $X_{c h}$ represents a vector of child characteristics (including age and number of siblings), while $Z_{c h}$ captures a vector of parental characteristics, including mother's educational attainment, mother's age at first birth, spouse's educational attainment, religion, and household wealth status. $\mu_{v}$ represents village level dummies that may capture spatial differences in child undernutrition and related early child outcomes.

The parameter of interest is $\beta_{1}$ in equation (1). A negative value implies polygyny leads to child undernutrition, measured by HAZ. However, polygyny is an endogenous decision, which is expected to be simultaneously determined by intended child investments. Polygyny decisions are also expected to be correlated with unobservable parental characteristics, which may also affect child nutritional investments. Thus, OLS estimation of equation (1) may produce biased estimates of $\beta_{1}$.

\footnotetext{
${ }^{5}$ Household welfare is measured using a wealth index. The wealth index is constructed using principal components analysis that combines ownership of durable goods, such as radio, bicycle, and car, with housing characteristics (Rutstein and Johnson 2004).
} 
We use an instrumental variable (IV) approach to investigate the effect of polygynous family structure on child undernutrition. An extensive literature exploits exogenous variation in birth patterns (e.g. twinning or the sex composition of siblings) to assess issues such as labor choices, the child quantity-quality tradeoff, and child growth (Rosenzweig and Wolpin 1980; Kaestner 1997). Angrist and Evans (1998) are the first to propose an instrument constructed from the sex composition of the first two children born in a family. They argue that parents have preferences for a mixed-sex composition of children and, hence, parents whose first two children are the same sex have a higher probability of adding children than those whose first two children had a mixed-sex composition.

We extend this argument to assert that men with two children of the same sex are consistently more likely to form a polygynous family than men whose first two children are of the opposite sex. Using the information from the male questionnaire of the 2008 and 2013 NDHS about preferences for numbers of boy and girl children, we find that the desire for a balanced sex composition in a man's children is strong, but slightly different across zones (Table 2). The Gender Preference Index is defined for all members of the NDHS men sample (married, unmarried, with or without children) who indicate that the ideal number of children they would prefer in their household is more than zero. The Index is zero if the man ideally prefers only girls, 0.5 if the man prefers equal numbers of boys and girls, and one if the man prefers only boys.

Table 2: Men's preferences for balanced sibling sex composition, by area

\begin{tabular}{|c|c|c|c|c|c|c|c|c|c|c|}
\hline & \multicolumn{2}{|c|}{$\begin{array}{l}\text { Married men in } \\
\text { polygynous } \\
\text { unions (\%) }\end{array}$} & \multicolumn{2}{|c|}{$\begin{array}{c}\text { Gender } \\
\text { Preference Index, } \\
\text { mean }\end{array}$} & \multicolumn{2}{|c|}{$\begin{array}{l}\text { Gender } \\
\text { Preference Index, } \\
\text { median }\end{array}$} & \multicolumn{2}{|c|}{$\begin{array}{l}\text { Married men } \\
\text { sample size }\end{array}$} & \multicolumn{2}{|c|}{$\begin{array}{c}\text { Men who want } \\
\text { children sample } \\
\text { size }\end{array}$} \\
\hline & 2008 & 2013 & 2008 & 2013 & 2008 & 2013 & 2008 & 2013 & 2008 & 2013 \\
\hline National & 12 & 9 & 0.59 & 0.59 & 0.57 & 0.57 & 2,231 & 16,823 & 1,969 & 16,398 \\
\hline \multicolumn{11}{|l|}{ By zones } \\
\hline North Central & 12 & 9 & 0.59 & 0.56 & 0.57 & 0.50 & 412 & 2,961 & 406 & 2,721 \\
\hline North East & 21 & 12 & 0.62 & 0.60 & 0.60 & 0.58 & 405 & 2,793 & 291 & 2,485 \\
\hline North West & 16 & 14 & 0.60 & 0.62 & 0.60 & 0.60 & 529 & 4,085 & 359 & 4,044 \\
\hline South East & 4 & 2 & 0.59 & 0.57 & 0.57 & 0.50 & 259 & 1,578 & 257 & 1,600 \\
\hline South South & 9 & 3 & 0.58 & 0.58 & 0.50 & 0.57 & 302 & 2,886 & 295 & 2,965 \\
\hline South West & 6 & 4 & 0.56 & 0.57 & 0.50 & 0.50 & 324 & 2,520 & 361 & 2,583 \\
\hline
\end{tabular}

Sources: Authors; Nigerian Demographic and Health Survey (NDHS), 2013 and 2008

Note: The Gender Preference Index is defined for all members of the NDHS men sample (married or unmarried, with or without children) who indicate the ideal number of children is more than zero. The Index is zero if the man ideally prefers only girls, 0.5 if the man prefers an equal number of boys and girls, and one if the man prefers only boys.

As we are focusing on early child nutritional outcomes in a context where preferences for mixed sex composition is dominant (Rossi and Rouanet 2015; Norling 2018; Kaestner 1997), we construct an instrument identifying children born to first wives whose first and second born children are the same sex, i.e., only sons [boy-boy] or only daughters [girl-girl]. Only the first two children of the first wife are considered.

We exploit the exogenous variation in polygyny generated by the presence of first and second born same sex siblings and estimate the following two-sample instrumental variable (IV) approach:

$$
\begin{aligned}
& \text { polygyny }_{h}=\alpha_{0}+\alpha_{1} \text { sa⿸厃㔾me_sex } \\
& Y_{c h}+\alpha_{2} X_{h}+\alpha_{3} Z_{h}+\mu_{v}+\beta_{h}+\beta_{1} \text { polygyny } \\
& \text { ch }+\beta_{2} X_{c h}+\beta_{3} Z_{c h}+\mu_{v}+\varepsilon_{c h}
\end{aligned}
$$

where equation (2) stands for the first-stage regression, while equation (3) represents the secondstage regressions. The variable same_sex s $_{h}$ is an indicator for children whose mother is a first wife with first and second born children of the same sex. Other notations are similar with those in equation (1). Theoretically, a positive value of $\alpha_{1}$ in equation (2) and a negative value of $\beta_{1}$ in 
equation (3) implies that a polygynous family structure has a detrimental effect on child nutrition outcomes (Becker 1974; Rosenzweig and Wolpin 1980).

The identification of the effects of polygyny on child undernutrition is not without potential threats. To conduct causal inference on the effect of polygyny on early child undernutrition, we must confirm two identifying assumptions of the instrument. First, the same-sex instrument must be relevant and, hence, predict polygyny for those parents with two or more children. This is expected to hold in view of the preferences of men for their children to have a mixed-sex composition. This can be empirically tested using the first-stage regression in equation (2) as well as appropriate statistical tests to verify that this is indeed the case.

Second, the instrument should be valid, and hence uncorrelated with the error term in the second-stage equation. The latter requirement is more demanding as it implies that sex composition of first-born siblings should not directly affect early childhood nutritional outcomes other than through polygyny and other control characteristics, such as family size, parental education, and wealth indicators. Although the sex of a child is completely determined by nature, this may not be the case if parents have full control over the births and sexes of their children. For instance, abortion decisions based on the sex of the fetus may invalidate the instrument. However, the prevalence of selective abortion can be empirically and indirectly tested in our dataset. For instance, if selective abortion is widespread, the genders of consecutive births are expected to be correlated. We can also explore whether the sex ratio of births varies across birth order.

Recent studies show that birth patterns may influence some parental behavior and sibling outcomes directly other than through family structure (Rosenzweig and Wolpin 2000; Conley and Glaube 2006; Rosenzweig and Zhang 2009; Deschênes 2007; Dahl and Moretti 2008; Black, Devereux, Salvanes 2005). For instance, Conley and Glaube (2006) find that the same sex of the first two children increased the likelihood of having three or more children, which affects the educational outcomes of the children. ${ }^{6}$ As we are controlling for number of children and focusing on early nutritional outcomes, the first threat may not be a major problem. In an effort to uncover potential correlations, we run simple linear probability estimates of indicator variables for parents whose first two children are the same sex on some observable parent and child characteristics.

Finally, we also estimate the effects by decomposing the same sex indicator into two indicators, both boys and both girls. By doing so, we are able to conduct an over-identification (Sargan) test on the validity of these instruments. Fertility preferences and associated cultural norms as well as other unobserved factors that may influence child undernutrition are expected to be correlated with local attributes. Thus, in all regressions we cluster standard errors at the village level. We also examine whether polygyny's effects on child nutritional status vary with household wealth status and levels of urbanization. These results enable us to better understand which children are affected most.

\section{EMPIRICAL RESULTS ON IMPACTS OF POLYGYNY ON CHILD NUTRITIONAL OUTCOMES}

\section{Estimates of the effect of same sex sibling composition on polygyny}

We estimate the first stage regression of the same sex sibling indicator on polygyny with and without covariates and state-level fixed effects for the pooled surveys and for each survey separately (2008 and 2013). The results (Table 3) indicate that the same sex sibling indicator appears with the expected sign. The positive and statistically significant (at one percent) effect on

\footnotetext{
${ }^{6}$ Rosenzweig and Wolpin (2000) argue that same sex siblings may involve reduced childbearing expenditures for parents. This is probably because they can share clothing and footwear.
} 
polygyny of the occurrence of same sex siblings in the first two births is an indication that same sex siblings predict polygyny.

Table 3. Effect of the presence of same sex siblings on polygyny outcomes

\begin{tabular}{|c|c|c|c|c|c|}
\hline & & Pooled & & 2008 & 2013 \\
\hline & (1) & (2) & (3) & (4) & (5) \\
\hline Same sex & $0.018^{\star \star \star}$ & $0.015^{\star \star \star}$ & $0.016^{\star \star \star}$ & $0.014^{\star \star}$ & $0.019 * \star$ \\
\hline & $(0.005)$ & $(0.006)$ & $(0.006)$ & $(0.007)$ & $(0.008)$ \\
\hline Mother's educational attainment & & $-0.018^{\star \star \star}$ & $-0.016^{\star \star \star}$ & $-0.015^{\star \star \star}$ & $-0.014^{\star \star \star}$ \\
\hline & & $(0.001)$ & $(0.001)$ & $(0.002)$ & $(0.001)$ \\
\hline Spouse's educational attainment & & $-0.003^{\star \star \star}$ & $-0.003^{\star \star *}$ & $-0.005^{\star * *}$ & $-0.002^{*}$ \\
\hline & & $(0.001)$ & $(0.001)$ & $(0.001)$ & $(0.001)$ \\
\hline Age of mother at first birth & & 0.001 & $0.001^{*}$ & $0.004^{\star \star \star}$ & 0.000 \\
\hline & & $(0.001)$ & $(0.001)$ & $(0.001)$ & $(0.001)$ \\
\hline Wealth index quintile (Poorest is & & & & & \\
\hline 2nd quintile & & $0.034^{\star \star \star}$ & $0.037^{\star \star \star}$ & $0.094^{\star \star \star}$ & $-0.031^{*}$ \\
\hline & & $(0.012)$ & $(0.012)$ & $(0.016)$ & $(0.016)$ \\
\hline 3rd quintile & & $0.058^{\star \star \star}$ & $0.069^{\star \star \star}$ & $0.118^{\star * \star}$ & 0.006 \\
\hline & & $(0.015)$ & $(0.015)$ & $(0.019)$ & $(0.021)$ \\
\hline 4th quintile & & $0.065^{\star \star \star}$ & $0.081^{\star \star \star}$ & $0.139 * \star \star$ & 0.018 \\
\hline & & $(0.017)$ & $(0.017)$ & $(0.023)$ & $(0.024)$ \\
\hline Richest quintile & & $0.061^{\star \star *}$ & $0.073^{\star \star \star}$ & $0.125^{\star \star \star}$ & 0.016 \\
\hline & & $(0.020)$ & $(0.020)$ & $(0.027)$ & $(0.029)$ \\
\hline Ethnicity (Yoruba is base) & & & & & \\
\hline Hausa & & $0.068^{\star \star \star}$ & $0.069 * \star \star$ & $0.070^{\star \star \star}$ & $0.061^{\star \star \star}$ \\
\hline & & $(0.015)$ & $(0.016)$ & $(0.022)$ & $(0.020)$ \\
\hline Fulani & & 0.006 & 0.001 & $0.052^{*}$ & -0.014 \\
\hline & & $(0.020)$ & $(0.021)$ & $(0.029)$ & $(0.029)$ \\
\hline Igbo & & $-0.128^{\star \star \star}$ & $-0.122^{\star \star \star}$ & $-0.103^{\star \star *}$ & $-0.150 * \star \star$ \\
\hline & & $(0.014)$ & $(0.014)$ & $(0.018)$ & $(0.016)$ \\
\hline Others & & $-0.028^{\star *}$ & $-0.031^{\star *}$ & -0.002 & $-0.050^{\star \star \star}$ \\
\hline & & $(0.012)$ & $(0.013)$ & $(0.017)$ & $(0.016)$ \\
\hline Level of urbanization, night-time & $=0$ is base & & & & \\
\hline $\mathrm{DN}>0 \& \mathrm{DN} \leqslant 13$ & & $-0.044^{\star \star \star}$ & $-0.047^{\star \star \star}$ & $-0.056^{\star \star *}$ & $-0.059 * * *$ \\
\hline & & $(0.013)$ & $(0.014)$ & $(0.020)$ & $(0.016)$ \\
\hline$D N>13 \& D N \leqslant 48$ & & $-0.105^{\star \star \star}$ & $-0.105^{\star \star \star}$ & $-0.133^{\star \star \star}$ & $-0.115^{\star \star \star}$ \\
\hline & & $(0.015)$ & $(0.016)$ & $(0.021)$ & $(0.020)$ \\
\hline $\mathrm{DN}>48$ & & $-0.126^{\star \star \star}$ & $-0.138^{\star \star *}$ & $-0.179 * \star *$ & $-0.124^{\star \star \star}$ \\
\hline & & $(0.017)$ & $(0.018)$ & $(0.022)$ & $(0.022)$ \\
\hline Year dummy (2013) & -0.003 & 0.007 & 0.004 & & \\
\hline & $(0.005)$ & $(0.010)$ & $(0.010)$ & & \\
\hline State-level fixed-effects? & No & No & Yes & Yes & Yes \\
\hline R-squared & 0.05 & 0.10 & 0.11 & 0.11 & 0.11 \\
\hline Observations & 31,993 & 31,993 & 31,993 & 13,935 & 18,058 \\
\hline
\end{tabular}

Source: Authors; Nigerian Demographic and Health Survey (NDHS), 2013 and 2008; and NOAA's National Geophysical Data Center. Notes: $\mathrm{DN}=$ digital number; values range from 0 to 63 . Standard errors are clustered at village level and given in parentheses. $* \star \star ~ p<0.01$; ** $p<0.05 ;{ }^{*} p<0.10$.

The results also indicate that polygyny is correlated with a range of household characteristics as well as different levels of urbanization. In particular, the polygynous family structure is explained by household wealth index categories, ethnicity, and urbanization. Many of these correlations are similar to those in other studies which point to the importance of observable factors, such as education, urbanization and ethnicity, in driving polygynous family structure (e.g. Smith-Greenway and Trinitapoli 2014; Arthi and Fenske 2018). For instance, we found that Hausa and Fulani households are more likely to form polygynous unions compared to Igbo and Yoruba households. 
The estimated result for the level of urbanization (proxied by night-time light) is interesting. The level affects the probability of polygyny negatively and significantly, and the effect increases with level of urbanization.

Before examining the effect of polygyny on child nutrition, we briefly discuss the quality of the selected instruments. We conduct two tests to probe their validity. First, in order to investigate whether the instrument is likely to be exogenous, we estimate a probit model regressing the same sex sibling indicator on parental characteristics. The results in Table 4 show that all parental characteristics are statistically insignificant, which provides additional evidence that the occurrence of same sex siblings in the first two births is unrelated to observable characteristics and is likely exogenous.

Table 4: Effect of parental characteristics on the presence of same sex siblings

\begin{tabular}{|c|c|c|c|}
\hline & Pooled & 2008 & 2013 \\
\hline \multirow[t]{2}{*}{ Number of children } & 0.002 & -0.005 & 0.008 \\
\hline & $(0.004)$ & $(0.005)$ & $(0.005)$ \\
\hline \multirow[t]{2}{*}{ Mother's educational attainment } & 0.003 & -0.002 & 0.006 \\
\hline & $(0.003)$ & $(0.004)$ & $(0.004)$ \\
\hline \multirow[t]{2}{*}{ Spouse's educational attainment } & -0.001 & -0.001 & -0.001 \\
\hline & $(0.002)$ & $(0.003)$ & $(0.003)$ \\
\hline \multirow[t]{2}{*}{ Age of mother at first birth } & 0.002 & 0.000 & 0.003 \\
\hline & $(0.002)$ & $(0.004)$ & $(0.003)$ \\
\hline \multicolumn{4}{|c|}{ Wealth index quintile (Poorest is base) } \\
\hline \multirow[t]{2}{*}{$2^{\text {nd }}$ quintile } & $0.043^{*}$ & 0.054 & 0.039 \\
\hline & $(0.026)$ & $(0.038)$ & $(0.034)$ \\
\hline \multirow[t]{2}{*}{$3^{\text {rd }}$ quintile } & 0.035 & 0.064 & 0.015 \\
\hline & $(0.029)$ & $(0.041)$ & $(0.041)$ \\
\hline \multirow[t]{2}{*}{$4^{\text {th }}$ quintile } & 0.029 & 0.061 & 0.008 \\
\hline & $(0.036)$ & $(0.050)$ & $(0.051)$ \\
\hline \multirow[t]{2}{*}{ Richest quintile } & 0.028 & 0.055 & 0.007 \\
\hline & $(0.045)$ & $(0.064)$ & $(0.063)$ \\
\hline \multicolumn{4}{|l|}{ Ethnicity (Yoruba is base) } \\
\hline \multirow[t]{2}{*}{ Hausa } & 0.014 & -0.029 & 0.047 \\
\hline & $(0.033)$ & $(0.051)$ & $(0.045)$ \\
\hline \multirow[t]{2}{*}{ Fulani } & 0.063 & 0.017 & $0.107^{*}$ \\
\hline & $(0.042)$ & $(0.063)$ & $(0.059)$ \\
\hline \multirow[t]{2}{*}{ Igbo } & $-0.085^{\star *}$ & $-0.086^{\star}$ & $-0.085^{\star}$ \\
\hline & $(0.034)$ & $(0.052)$ & $(0.049)$ \\
\hline \multirow[t]{2}{*}{ Others } & -0.030 & -0.028 & -0.026 \\
\hline & $(0.029)$ & $(0.045)$ & $(0.039)$ \\
\hline \multicolumn{4}{|c|}{ Level of urbanization, night-time lights ( $\mathrm{DN}=0$ is base) } \\
\hline \multirow[t]{2}{*}{$\mathrm{DN}>0 \& \mathrm{DN} \leqslant 13$} & -0.027 & 0.012 & $-0.055^{\star}$ \\
\hline & $(0.025)$ & $(0.039)$ & $(0.033)$ \\
\hline \multirow[t]{2}{*}{$\mathrm{DN}>13 \& \mathrm{DN} \leqslant 48$} & 0.030 & 0.038 & 0.022 \\
\hline & $(0.034)$ & $(0.050)$ & $(0.045)$ \\
\hline \multirow[t]{2}{*}{$\mathrm{DN}>48$} & -0.036 & 0.047 & -0.081 \\
\hline & $(0.044)$ & $(0.070)$ & $(0.056)$ \\
\hline \multirow[t]{2}{*}{ Year dummy (2013) } & -0.005 & & \\
\hline & $(0.003)$ & & \\
\hline \multirow[t]{2}{*}{ Constant } & 10.101 & 0.040 & -0.113 \\
\hline & $(6.914)$ & $(0.094)$ & $(0.088)$ \\
\hline Observations & 31,993 & 13,935 & 18,058 \\
\hline
\end{tabular}

Source: Authors; Nigerian Demographic and Health Survey (NDHS), 2013 and 2008; and NOAA's National Geophysical Data Center. Notes: $\mathrm{DN}=$ digital number; values range from 0 to 63 . Standard errors are clustered at village level and given in parentheses. ${ }^{* \star *} \mathrm{p}<0.01$; ${ }^{* *} p<0.05 ;{ }^{*} p<0.10$. 
Second, we check whether the same sex indicator has a direct effect on child nutritional outcomes. To do so, we regress child nutritional outcomes on the same sex indicator and other covariates. The results show that the occurrence of same sex siblings in the first two births has no significant effect, confirming that the same sex indicator has no direct effect on child nutritional outcomes (see Appendix Table A1). We also estimate the relationship between child health and the occurrence of same sex siblings for the sample of monogamous women as a possible placebo analysis (see Appendix Table A2). We find there is no significant relationship between child nutritional outcomes and same sex sibling composition. This result confirms that there is no reduced-form relationship between child undernutrition and same sex sibling composition.

Finally, we report different tests to detect whether the instrument suffers from a weak-instrument problem from the first stage and second stage (the last rows of Tables 5 and 6 ). All tests are significant, indicating that our analysis does not suffer from a weak-instrument problem.

\section{Instrumental variable estimates of child undernutrition}

Tables 5 and 6 show the regression results using ordinary least squares (OLS) and a two-sample instrumental variable (IV) approaches for child HAZ and stunting, respectively. The IV estimates for child undernutrition are similar in sign with the OLS estimates - the results obtained from OLS and IV estimates confirm that polygyny has significant negative effects on child undernutrition. The IV estimate is an Average Treatment Effect (ATE). Consequently, comparing IV and OLS results is not straightforward. The IV estimates for the variables of interest are larger than the OLS estimates. This is because our data shows that the likelihood that a household switches to polygyny by drawing same sex children is a function of wealth. Poorer households switch to polygyny after drawing same-sex children with a greater likelihood than richer households, which implies that IV is estimating the effect of polygyny for these poorer households, while OLS measures the effect of polygyny on the average household.

Comparing the unconditional and conditional estimates in Tables 5 and 6 provides insights on potential mechanisms through which polygyny can lead to lower child nutritional outcomes. For instance, the estimates on the effect of polygyny in the pooled regressions almost halve for $\mathrm{HAZ}$ when we control for child characteristics, socioeconomic characteristics, wealth indicators, and state-level fixed effects, suggesting, as expected, that part of the link between polygyny and child undernutrition is mediated through these channels. Nevertheless, the estimated coefficients on polygyny remain sizeable and strongly statistically significant even after controlling for these characteristics. This analysis does not provide insights as to what are the possible reasons. Polygynous households may have different behavioral practices towards children, skepticism of modern medical practices, and reduced bargaining power for women. These factors associated with polygyny could be associated with higher rates of child undernutrition for which we did not control (Le Strat et al. 2011; Smith-Greenway and Trinitapoli 2014; Wagner and Rieger 2015; Arthi and Fenske 2018). Therefore, our preferred estimates are from the IV models that control for child, parental, and state-level fixed effects. 
Table 5: Ordinary Least Squares and Instrumental Variable estimates of the effect of polygyny on child height-for-age z-scores

\begin{tabular}{|c|c|c|c|c|c|c|c|c|}
\hline & \multicolumn{6}{|c|}{ Pooled } & \multirow{3}{*}{$\begin{array}{c}2008 \\
\text { IV } \\
\text { (7) }\end{array}$} & \multirow{3}{*}{$\begin{array}{c}2013 \\
\text { IV } \\
\text { (8) }\end{array}$} \\
\hline & \multirow[b]{2}{*}{ (1) } & \multicolumn{2}{|l|}{ OLS } & \multicolumn{3}{|c|}{ IV } & & \\
\hline & & (2) & (3) & (4) & (5) & (6) & & \\
\hline \multirow[t]{2}{*}{ Polygyny } & $-0.318^{\star \star \star}$ & $-0.158^{\star \star \star}$ & $-0.158^{\star \star \star}$ & $-0.707^{\star \star \star}$ & $-0.510^{\star * \star}$ & $-0.299 * \star \star$ & $-0.235^{\star}$ & $-0.323^{\star * *}$ \\
\hline & $(0.013)$ & $(0.013)$ & $(0.013)$ & $(0.036)$ & $(0.118)$ & $(0.127)$ & $(0.113)$ & $(0.081)$ \\
\hline \multirow[t]{2}{*}{ Child is boy } & & $-0.093^{\star \star \star}$ & $-0.093^{\star \star \star}$ & & $-0.085^{\star \star \star}$ & $-0.092^{\star \star \star}$ & $-0.107^{\star \star \star}$ & $-0.082^{\star \star *}$ \\
\hline & & $(0.010)$ & $(0.010)$ & & $(0.010)$ & $(0.010)$ & $(0.016)$ & $(0.013)$ \\
\hline \multirow[t]{2}{*}{ Age of child } & & $-0.012^{\star \star \star}$ & $-0.012^{\star \star \star}$ & & $-0.012^{\star \star \star}$ & $-0.012^{\star \star \star}$ & $-0.011^{\star \star \star}$ & $-0.013^{\star * *}$ \\
\hline & & $(0.000)$ & $(0.000)$ & & $(0.000)$ & $(0.000)$ & $(0.001)$ & $(0.000)$ \\
\hline \multirow[t]{2}{*}{ Number of children } & & $0.005^{\star \star}$ & $0.005^{\star *}$ & & $0.021^{\star \star \star}$ & $0.013^{\star \star \star}$ & $0.011^{*}$ & $0.015^{\star \star \star}$ \\
\hline & & $(0.002)$ & $(0.002)$ & & $(0.004)$ & $(0.004)$ & $(0.006)$ & $(0.005)$ \\
\hline \multirow[t]{2}{*}{ Mother's educ. attainment } & & $0.013^{\star \star \star}$ & $0.013^{\star \star \star}$ & & 0.004 & $0.005^{*}$ & $0.007^{*}$ & 0.005 \\
\hline & & $(0.002)$ & $(0.002)$ & & $(0.003)$ & $(0.003)$ & $(0.004)$ & $(0.003)$ \\
\hline \multirow[t]{2}{*}{ Spouse's educ. attainment } & & $0.003^{\star *}$ & $0.003^{\star *}$ & & 0.002 & 0.000 & -0.002 & $0.003^{*}$ \\
\hline & & $(0.001)$ & $(0.001)$ & & $(0.002)$ & $(0.002)$ & $(0.002)$ & $(0.002)$ \\
\hline \multirow[t]{2}{*}{ Age of mother at first birth } & & $0.005^{\star \star \star}$ & $0.005^{\star \star \star}$ & & $0.010 * \star \star$ & $0.004^{\star *}$ & 0.002 & $0.005^{\star *}$ \\
\hline & & $(0.001)$ & $(0.001)$ & & $(0.002)$ & $(0.002)$ & $(0.002)$ & $(0.002)$ \\
\hline \multicolumn{9}{|c|}{ Wealth index quintile (Poorest is base) } \\
\hline \multirow[t]{2}{*}{$2^{\text {nd }}$ quintile } & & $0.073^{\star \star \star}$ & $0.073^{\star \star \star}$ & & $0.103^{\star \star *}$ & $0.075^{\star \star \star}$ & $0.086^{\star *}$ & 0.041 \\
\hline & & $(0.020)$ & $(0.020)$ & & $(0.022)$ & $(0.021)$ & $(0.034)$ & $(0.027)$ \\
\hline \multirow[t]{2}{*}{$3^{\text {rd }}$ quintile } & & $0.162^{\star \star \star}$ & $0.162^{\star \star \star}$ & & $0.209 * \star \star$ & $0.159^{\star \star \star}$ & $0.143^{\star \star *}$ & $0.122^{\star * *}$ \\
\hline & & $(0.023)$ & $(0.023)$ & & $(0.026)$ & $(0.026)$ & $(0.040)$ & $(0.035)$ \\
\hline \multirow[t]{2}{*}{$4^{\text {th }}$ quintile } & & $0.251^{\star \star \star}$ & $0.251^{\star \star \star}$ & & $0.302^{\star \star \star}$ & $0.243^{\star \star \star}$ & $0.221^{\star \star \star}$ & $0.198^{\star \star \star}$ \\
\hline & & $(0.025)$ & $(0.025)$ & & $(0.028)$ & $(0.028)$ & $(0.045)$ & $(0.037)$ \\
\hline \multirow[t]{2}{*}{ Richest quintile } & & $0.366^{\star \star \star}$ & $0.366^{\star \star \star}$ & & $0.414^{\star \star \star}$ & $0.359 * \star \star$ & $0.335^{\star \star \star}$ & $0.308^{\star \star \star}$ \\
\hline & & $(0.031)$ & $(0.031)$ & & $(0.034)$ & $(0.034)$ & $(0.054)$ & $(0.044)$ \\
\hline Level of urbanization, night-time & lights (DN & $=0$ is base) & & & & & & \\
\hline $\mathrm{DN}>0 \& \mathrm{DN} \leq 13$ & & $0.037^{*}$ & $0.037^{*}$ & & 0.013 & -0.018 & 0.005 & -0.014 \\
\hline & & $(0.022)$ & $(0.022)$ & & $(0.024)$ & $(0.024)$ & $(0.035)$ & $(0.030)$ \\
\hline $\mathrm{DN}>13 \& \mathrm{DN} \leq 48$ & & 0.025 & 0.025 & & -0.035 & -0.048 & 0.032 & -0.057 \\
\hline & & $(0.027)$ & $(0.027)$ & & $(0.031)$ & $(0.029)$ & $(0.045)$ & $(0.036)$ \\
\hline $\mathrm{DN}>48$ & & $0.112^{\star \star \star}$ & $0.112^{\star \star \star}$ & & 0.041 & 0.003 & 0.109 & -0.020 \\
\hline & & $(0.032)$ & $(0.032)$ & & $(0.035)$ & $(0.039)$ & $(0.067)$ & $(0.046)$ \\
\hline Ethnicity (Yoruba is base) & & & & & & & & \\
\hline Hausa & & 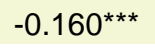 & $-0.160^{\star \star \star}$ & & $-0.097^{\star \star \star}$ & 0.049 & 0.008 & $0.106^{\star \star}$ \\
\hline & & $(0.024)$ & $(0.024)$ & & $(0.029)$ & $(0.036)$ & $(0.050)$ & $(0.047)$ \\
\hline Fulani & & 0.037 & 0.037 & & $0.077^{\star \star}$ & $0.116^{\star \star \star}$ & 0.085 & $0.158^{\star \star \star}$ \\
\hline & & $(0.031)$ & $(0.031)$ & & $(0.035)$ & $(0.037)$ & $(0.056)$ & $(0.046)$ \\
\hline Igbo & & $0.243^{\star \star \star}$ & $0.243^{\star \star \star}$ & & $0.182^{\star \star \star}$ & $0.084^{\star \star}$ & 0.067 & $0.140^{\star \star \star}$ \\
\hline & & $(0.024)$ & $(0.024)$ & & $(0.027)$ & $(0.039)$ & $(0.057)$ & $(0.049)$ \\
\hline Others & & 0.035 & 0.035 & & $0.043^{*}$ & -0.005 & -0.005 & 0.022 \\
\hline & & $(0.021)$ & $(0.021)$ & & $(0.022)$ & $(0.028)$ & $(0.041)$ & $(0.035)$ \\
\hline Year dummy (2013) & $0.090 * \star \star$ & $0.075^{\star \star \star}$ & $0.075^{\star \star \star}$ & $0.251^{\star \star \star}$ & $0.083^{\star * \star}$ & $0.088^{\star \star \star}$ & & \\
\hline & $(0.015)$ & $(0.015)$ & $(0.015)$ & $(0.017)$ & $(0.016)$ & $(0.015)$ & & \\
\hline State-level fixed-effects? & No & No & Yes & No & No & Yes & Yes & Yes \\
\hline Weak-Identification tests: & & & & & & & & \\
\hline Keibergen-Paap Wald rk F stat. & & & & 570.05 & 188.67 & 153.52 & 116.67 & 161.32 \\
\hline Cragg-Donald Wald F statistic & & & & 455.09 & 198.77 & 162.36 & 122.09 & 165.97 \\
\hline Weak-instrument-robust, inferenc & & & & & & & & \\
\hline Anderson-Rubin F statistic & & & & 77.02 & 31.95 & 21.72 & 10.17 & 24.46 \\
\hline Stock-Wright S statistic & & & & 41.31 & 33.92 & 21.34 & 20.49 & 48.98 \\
\hline R-squared & 0.04 & 0.12 & 0.14 & 0.03 & 0.06 & 0.12 & 0.08 & 0.14 \\
\hline Observations & 31,993 & 31,993 & 31,993 & 31,993 & 31,993 & 31,993 & 13,935 & 18,058 \\
\hline
\end{tabular}

Source: Authors; Nigerian Demographic and Health Survey (NDHS), 2013 and 2008; and NOAA's National Geophysical Data Center. Notes: Standard errors are clustered at village level and given in parentheses. ${ }^{* *} p<0.01 ;{ }^{* *} p<0.05 ;{ }^{*} p<0.10$. 
Table 6: Ordinary Least Squares and Instrumental Variable estimates of the effect of polygyny on child stunting rates

\begin{tabular}{|c|c|c|c|c|c|c|c|c|}
\hline & \multicolumn{6}{|c|}{ Pooled } & \multirow{3}{*}{$\begin{array}{c}2008 \\
\text { IV } \\
\text { (7) }\end{array}$} & \multirow{3}{*}{$\begin{array}{c}2013 \\
\text { IV } \\
(8)\end{array}$} \\
\hline & & OLS & & & IV & & & \\
\hline & (1) & (2) & (3) & (4) & (5) & (6) & & \\
\hline \multirow[t]{2}{*}{ Polygyny } & $0.519 * * \star$ & $0.235^{\star \star \star}$ & $0.235^{\star \star \star}$ & $0.884^{\star \star \star}$ & $0.600 * \star \star$ & $0.448^{\star \star \star}$ & $0.347^{\star \star \star}$ & $0.448^{\star \star *}$ \\
\hline & $(0.008)$ & $(0.006)$ & $(0.006)$ & $(0.025)$ & $(0.065)$ & $(0.069)$ & $(0.102)$ & $(0.086)$ \\
\hline \multirow[t]{2}{*}{ Child is boy } & & $0.056^{\star \star \star}$ & $0.056^{\star \star \star}$ & & $0.048^{\star \star \star}$ & $0.048^{\star \star \star}$ & $0.057^{\star \star \star}$ & $0.041^{\star \star *}$ \\
\hline & & $(0.005)$ & $(0.005)$ & & $(0.006)$ & $(0.005)$ & $(0.008)$ & $(0.007)$ \\
\hline \multirow[t]{2}{*}{ Age of child } & & $0.004^{\star \star \star}$ & $0.004^{\star \star \star}$ & & $0.004^{\star \star \star}$ & $0.004^{\star \star \star}$ & $0.003^{\star \star \star}$ & $0.004^{\star * \star}$ \\
\hline & & $(0.000)$ & $(0.000)$ & & $(0.000)$ & $(0.000)$ & $(0.000)$ & $(0.000)$ \\
\hline \multirow[t]{2}{*}{ Number of children } & & $0.007^{\star \star *}$ & $0.007^{\star \star \star}$ & & $-0.009^{* \star \star}$ & $-0.006^{\star \star \star}$ & -0.005 & $-0.006^{\star \star}$ \\
\hline & & $(0.001)$ & $(0.001)$ & & $(0.002)$ & $(0.002)$ & $(0.003)$ & $(0.003)$ \\
\hline \multirow[t]{2}{*}{ Mother's educ. attainment } & & $-0.005^{\star \star \star}$ & $-0.005^{\star \star \star}$ & & $0.004^{\star \star}$ & 0.001 & -0.001 & 0.002 \\
\hline & & $(0.001)$ & $(0.001)$ & & $(0.001)$ & $(0.001)$ & $(0.002)$ & $(0.002)$ \\
\hline \multirow[t]{2}{*}{ Spouse's educ. attainment } & & -0.001 & -0.001 & & 0.001 & 0.001 & $0.003^{\star *}$ & -0.000 \\
\hline & & $(0.001)$ & $(0.001)$ & & $(0.001)$ & $(0.001)$ & $(0.001)$ & $(0.001)$ \\
\hline \multirow[t]{2}{*}{ Age of mother at first birth } & & $0.010^{\star \star \star}$ & $0.010^{\star \star \star}$ & & $0.004^{\star \star \star}$ & $0.003^{\star \star *}$ & $0.004^{\star \star \star}$ & $0.003^{\star \star *}$ \\
\hline & & $(0.001)$ & $(0.001)$ & & $(0.001)$ & $(0.001)$ & $(0.001)$ & $(0.001)$ \\
\hline \multicolumn{9}{|c|}{ Wealth index quintile (Poorest is base) } \\
\hline \multirow[t]{2}{*}{$2^{\text {nd }}$ quintile } & & 0.001 & 0.001 & & $-0.029 * *$ & $-0.024^{\star \star}$ & -0.029 & -0.009 \\
\hline & & $(0.010)$ & $(0.010)$ & & $(0.012)$ & $(0.011)$ & $(0.018)$ & $(0.014)$ \\
\hline \multirow[t]{2}{*}{$3^{\text {rd }}$ quintile } & & $-0.041^{\star \star \star}$ & $-0.041^{\star \star \star}$ & & $-0.088^{\star \star \star}$ & $-0.076^{\star \star \star}$ & $-0.083^{\star \star \star}$ & $-0.049 * \star *$ \\
\hline & & $(0.011)$ & $(0.011)$ & & $(0.015)$ & $(0.014)$ & $(0.021)$ & $(0.019)$ \\
\hline \multirow[t]{2}{*}{$4^{\text {th }}$ quintile } & & $-0.097^{\star * *}$ & $-0.097^{\star \star \star}$ & & $-0.148^{\star \star \star}$ & $-0.136^{\star \star \star}$ & 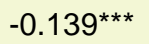 & $-0.108^{\star \star \star}$ \\
\hline & & $(0.013)$ & $(0.013)$ & & $(0.016)$ & $(0.015)$ & $(0.024)$ & $(0.021)$ \\
\hline \multirow[t]{2}{*}{ Richest quintile } & & $-0.143^{\star \star \star}$ & $-0.143^{\star \star \star}$ & & $-0.192^{\star \star \star}$ & $-0.181^{\star \star \star}$ & $-0.175^{\star \star \star}$ & $-0.159 * \star \star$ \\
\hline & & $(0.016)$ & $(0.016)$ & & $(0.019)$ & $(0.018)$ & $(0.028)$ & $(0.024)$ \\
\hline \multicolumn{9}{|c|}{ Level of urbanization, night-time lights ( $\mathrm{DN}=0$ is base) } \\
\hline \multirow[t]{2}{*}{$\mathrm{DN}>0 \& \mathrm{DN} \leq 13$} & & $-0.023^{\star \star}$ & $-0.023^{\star \star}$ & & 0.003 & 0.003 & -0.002 & 0.001 \\
\hline & & $(0.010)$ & $(0.010)$ & & $(0.014)$ & $(0.012)$ & $(0.018)$ & $(0.016)$ \\
\hline \multirow[t]{2}{*}{$\mathrm{DN}>13 \& \mathrm{DN} \leq 48$} & & -0.010 & -0.010 & & $0.052^{\star \star \star}$ & $0.038 * \star$ & 0.018 & $0.032^{*}$ \\
\hline & & $(0.013)$ & $(0.013)$ & & $(0.017)$ & $(0.016)$ & $(0.023)$ & $(0.019)$ \\
\hline $\mathrm{DN}>48$ & & $-0.040^{\star * *}$ & $-0.040^{* \star *}$ & & $0.035^{\star}$ & 0.030 & -0.002 & 0.036 \\
\hline & & $(0.015)$ & $(0.015)$ & & $(0.018)$ & $(0.019)$ & $(0.035)$ & $(0.023)$ \\
\hline Ethnicity (Yoruba is base) & & & & & & & & \\
\hline Hausa & & $0.218^{\star \star \star}$ & $0.218^{\star \star \star}$ & & $0.151^{\star \star \star}$ & $0.143^{\star \star \star}$ & $0.175^{\star \star \star}$ & $0.108^{\star \star \star}$ \\
\hline & & $(0.012)$ & $(0.012)$ & & $(0.016)$ & $(0.021)$ & $(0.028)$ & $(0.027)$ \\
\hline Fulani & & $0.162^{\star \star \star}$ & $0.162^{\star \star \star}$ & & $0.118^{\star \star \star}$ & $0.121 * \star \star$ & $0.140^{\star \star \star}$ & $0.096 * \star \star$ \\
\hline & & $(0.016)$ & $(0.016)$ & & $(0.020)$ & $(0.022)$ & $(0.032)$ & $(0.027)$ \\
\hline Igbo & & $-0.047^{\star \star \star}$ & $-0.047^{\star \star \star}$ & & 0.015 & $0.056^{\star \star \star}$ & $0.070^{\star *}$ & 0.025 \\
\hline & & $(0.012)$ & $(0.012)$ & & $(0.015)$ & $(0.021)$ & $(0.031)$ & $(0.026)$ \\
\hline Others & & $0.097^{\star \star \star}$ & $0.097^{\star \star \star}$ & & $0.087^{\star \star \star}$ & $0.116^{\star \star \star}$ & $0.133^{\star \star \star}$ & $0.089 * \star \star$ \\
\hline & & $(0.011)$ & $(0.011)$ & & $(0.012)$ & $(0.017)$ & $(0.025)$ & $(0.021)$ \\
\hline Year dummy (2013) & $0.266^{\star \star \star}$ & $-0.035^{\star \star \star}$ & $-0.035^{\star \star \star}$ & 0.013 & $-0.044^{\star * \star}$ & $-0.047^{\star \star \star}$ & & \\
\hline & $(0.007)$ & $(0.008)$ & $(0.008)$ & $(0.011)$ & $(0.009)$ & $(0.008)$ & & \\
\hline State-level fixed-effects? & No & No & Yes & No & No & Yes & Yes & Yes \\
\hline Weak-identification tests: & & & & & & & & \\
\hline Keibergen-Paap Wald rk F stat. & & & & 510.05 & 278.67 & 178.67 & 116.67 & 161.32 \\
\hline Cragg-Donald Wald F statistic & & & & 435.09 & 288.77 & 188.77 & 122.09 & 165.97 \\
\hline Weak-instrument-robust, inferenc & & & & & & & & \\
\hline Anderson-Rubin F statistic & & & & 72.02 & 25.53 & 21.95 & 10.17 & 24.46 \\
\hline Stock-Wright S statistic & & & & 40.31 & 31.39 & 23.92 & 20.49 & 48.98 \\
\hline R-squared & 0.03 & 0.10 & 0.12 & 0.03 & 0.08 & 0.11 & 0.08 & 0.14 \\
\hline Observations & 31,993 & 31,993 & 31,993 & 31,993 & 31,993 & 31,993 & 13,935 & 18,058 \\
\hline
\end{tabular}

Source: Authors; Nigerian Demographic and Health Survey (NDHS), 2013 and 2008; and NOAA's National Geophysical Data Center. Notes: Standard errors are clustered at village level and given in parentheses. ${ }^{* *} p<0.01 ;{ }^{* *} p<0.05 ;{ }^{*} p<0.10$. 


\section{Heterogeneous impact of polygyny on child undernutrition by wealth status and level of urbanization}

Thus far our results have highlighted the detrimental effect of polygyny on child undernutrition. However, the estimated effect of polygyny on child undernutrition can differ among different sets of household characteristics and levels of urbanization. In this section, we allow for heterogeneity in the effect of polygyny by wealth status and urbanization. Capturing the differential effect of polygyny is important for identifying more prone groups or areas that may benefit from increased public investments for addressing child undernutrition.

First, we estimate the effect of polygyny by household wealth status (Table 7). Polygyny has a detrimental effect of polygyny on child undernutrition for all wealth classifications. However, the detrimental effects of polygyny on child HAZ and stunting are higher for poorer households. This may be due to polygynous families being characterized by many young children, which leads the children to compete for nutritional and financial resources (Basu 2000; Sellen 1999).

Table 7: Instrumental Variable estimates of the effect of polygyny on child height-for age z-score and stunting rates, by household wealth terciles

\begin{tabular}{|c|c|c|c|c|c|c|}
\hline & \multicolumn{3}{|c|}{ Height-for-Age z-score } & \multicolumn{3}{|c|}{ Stunting rate } \\
\hline & (1) & (2) & (3) & (4) & (5) & (6) \\
\hline & $\begin{array}{c}\text { Poorest } \\
\text { wealth tercile }\end{array}$ & $\begin{array}{l}\text { Middle wealth } \\
\text { tercile }\end{array}$ & $\begin{array}{l}\text { Wealthiest } \\
\text { tercile }\end{array}$ & $\begin{array}{c}\text { Poorest } \\
\text { wealth tercile }\end{array}$ & $\begin{array}{l}\text { Middle wealth } \\
\text { tercile }\end{array}$ & $\begin{array}{l}\text { Wealthiest } \\
\text { tercile }\end{array}$ \\
\hline \multirow[t]{2}{*}{ Polygyny } & $-0.809 \star \star \star$ & $-0.212^{\star \star}$ & -0.102 & $0.677^{\star \star \star}$ & $0.499 * \star \star$ & $0.557^{\star \star \star}$ \\
\hline & $(0.153)$ & $(0.103)$ & $(0.193)$ & $(0.136)$ & $(0.064)$ & $(0.092)$ \\
\hline Other controls & Yes & Yes & Yes & Yes & Yes & Yes \\
\hline State-level fixed-effects? & Yes & Yes & Yes & Yes & Yes & Yes \\
\hline Observations & 14,616 & 6,358 & 11,018 & 14,616 & 6,358 & 11,018 \\
\hline
\end{tabular}

Sources: Authors; Nigerian Demographic and Health Survey (NDHS), 2013 and 2008; and NOAA's National Geophysical Data Center. Notes: Standard errors are clustered at village level and given in parentheses. ${ }^{* * *} p<0.01 ;{ }^{* *} p<0.05 ;{ }^{*} p<0.10$

Second, we further allow for heterogeneity in the estimate of the effect of polygyny by level of urbanization (Table 8). We find a detrimental effect of polygyny on child undernutrition across all levels of urbanization. However, it has a greater effect on households who live in more urban areas. The nutritional status of young children in urban settings seems to be slightly more sensitive to polygyny family structure than for young children in rural households. This may be because urban expansion may increase demand for food items, which in turn, triggers increases in food prices. This may imply that urban expansion will adversely affect urban polygynous families disproportionally as they rely primarily on market purchases for their food to a much greater degree than do rural households (Cohen and Garrett 2010).

Table 8: Instrumental Variable estimates of the effect of polygyny on child height-for age z-score and stunting rates, by level of urbanization categories

\begin{tabular}{|c|c|c|c|c|c|c|c|c|}
\hline \multirow{3}{*}{$\begin{array}{r}\text { Level of urbanization } \\
\text { category: }\end{array}$} & \multicolumn{4}{|c|}{ Height-for-Age z-score } & \multicolumn{4}{|c|}{ Stunting rate } \\
\hline & (1) & (2) & (3) & (4) & (5) & (6) & (7) & (8) \\
\hline & 1 & 2 & 3 & 4 & 1 & 2 & 3 & 4 \\
\hline \multirow[t]{2}{*}{ Polygyny } & $-0.260 * \star$ & $-0.746^{\star \star *}$ & $-0.849 * *$ & $-0.970 * \star \star$ & $0.364^{\star \star *}$ & $0.888^{\star \star \star}$ & $0.820 * \star \star$ & $-1.570^{\star \star \star}$ \\
\hline & $(0.118)$ & $(0.283)$ & $(0.404)$ & $(0.534)$ & $(0.069)$ & $(0.203)$ & $(0.281)$ & $(0.534)$ \\
\hline Other controls & Yes & Yes & Yes & Yes & Yes & Yes & Yes & Yes \\
\hline State-level fixed-effects? & Yes & Yes & Yes & Yes & Yes & Yes & Yes & Yes \\
\hline Observations & 19,289 & 6,337 & 3,991 & 2,376 & 19,289 & 6,337 & 3,991 & 2,376 \\
\hline
\end{tabular}

Sources: Authors; Nigerian Demographic and Health Survey (NDHS), 2013 and 2008; and NOAA's National Geophysical Data Center Notes: Standard errors are clustered at village level and given in parentheses. ${ }^{* \star} p<0.01 ;{ }^{* *} p<0.05 ;{ }^{*} p<0.10$.

The levels of urbanization are based on satellite remote sensing of night-time lights. The level 1 category of urbanization is assigned to areas with no night-time lights or a digital number (DN) of zero; level 2 are areas with DN > 0 \& DN $\leqslant 13$; level 3 : DN > 13 \& DN $\leqslant 48$; and level 4: DN > 48. 


\section{CONCLUSIONS}

Polygyny remains prevalent in Nigeria where about one out of three children live in polygynous families. The prevalence of polygynous households did not change between the 2008 and 2013 Nigeria DHS surveys. Similarly, child undernutrition remains high in Nigeria with one out of three children under five years of age estimated to be stunted in 2013. The persistency of polygyny suggests that it may be informative to look beyond socioeconomic factors to sociocultural dimensions that includes polygyny to explain drivers of undernutrition in children.

While there is a growing research interest in exploring how social and cultural practices, such as polygyny, affect child nutrition, the nexus has not been decisively established because of the complexity of the relationships. Unobservable household characteristics may simultaneously influence both the decision to form a polygynous union and the decision to adequately nourish children. We tackle this issue using an instrumental variable approach applied to the 2008 and 2013 Nigeria DHS surveys. Based on evidence that men prefer families composed of both sons and daughters, we instrument polygyny with the gender of the first two births born to first wives and identify same sex first and second born children, i.e., only sons [boy boy] or only daughters [girl girl]. We then estimate the effect of polygyny on child anthropometric measures. We are treating polygyny as causal, although it is not actually polygyny that causes undernutrition. Polygyny could be associated with effects that do cause undernutrition, such as different childcare practices; skepticism of modern medical practices; reduced bargaining power of women within polygynous households and early marriages, all of which could influence child undernutrition. We further explore how this relationship varies by household wealth status and the level of urbanization of the community in which the household resides.

Our results show that the occurrence of same sex siblings in the first wife's first two births is a predictor of polygyny - men tend to form polygynous families if the first two children born are of the same sex. Consistent with previous studies (e.g., Sellen 1999; Smith-Greenaway and Trinitapoli 2014; Hadley 2005; Wagner and Rieger 2015; Arthi and Fenske 2018), we find a detrimental effect of polygyny on child undernutrition. The results show that the effect of polygyny on child nutritional status is substantially reduced when we control for child characteristics, household characteristics, and wealth indicators, suggesting that part of the link between polygyny and child undernutrition is mediated through these channels. Nevertheless, the estimated coefficients on polygyny remain sizeable and strongly statistically significant even after controlling for these characteristics. This analysis does not provide more detailed insights as to what are the possible reasons for this.

The results show that polygyny has a detrimental effect on child nutritional status for all wealth classifications. However, the detrimental effects are higher for poorer households. This may be due to polygynous families being characterized by many young children, which leads the children to compete for nutritional and financial resources. We also find that polygyny has a greater adverse effect on the nutritional status of children who live in urban areas.

Our results have broader implications for addressing child undernutrition both in Nigeria and more broadly across all West African countries. A key inference is that further explorations are needed of the wide range of channels through which polygyny could influence child undernutrition, such as different childcare practices and reduced women bargaining power associated with polygyny. Reducing poverty, improving women's access to education, and promoting overall economic development more generally could significantly reduce child undernutrition. 


\section{APPENDIX}

Table A1: Effect of same sex siblings on child height-for age z-score and stunting rates

\begin{tabular}{|c|c|c|}
\hline & $\begin{array}{l}\text { (1) } \\
\text { Height-for-Age } \\
\text { Z-score }\end{array}$ & $\begin{array}{c}\text { (2) } \\
\text { Stunting }\end{array}$ \\
\hline \multirow[t]{2}{*}{ First two children of first wife of father are of the same sex } & -0.014 & 0.006 \\
\hline & $(0.011)$ & $(0.005)$ \\
\hline \multirow[t]{2}{*}{ Child is boy } & $-0.093^{\star * \star}$ & $0.040^{\star \star *}$ \\
\hline & $(0.010)$ & $(0.005)$ \\
\hline \multirow[t]{2}{*}{ Age of child } & $-0.012^{\star \star \star}$ & $0.003^{\star \star *}$ \\
\hline & $(0.000)$ & $(0.000)$ \\
\hline \multirow[t]{2}{*}{ Number of children } & $0.005^{\star}$ & $-0.002^{\star *}$ \\
\hline & $(0.002)$ & $(0.001)$ \\
\hline \multirow[t]{2}{*}{ Mother's educational attainment } & $0.014^{\star \star \star}$ & $-0.007^{\star \star \star}$ \\
\hline & $(0.002)$ & $(0.001)$ \\
\hline \multirow[t]{2}{*}{ Spouse's educational attainment } & $0.003^{\star *}$ & $-0.002^{\star \star \star}$ \\
\hline & $(0.001)$ & $(0.001)$ \\
\hline \multirow[t]{2}{*}{ Age of mother at first birth } & $0.006^{\star \star \star}$ & $-0.003^{\star \star \star}$ \\
\hline & $(0.002)$ & $(0.001)$ \\
\hline \multicolumn{3}{|l|}{ Wealth index quintile (Poorest is base) } \\
\hline \multirow[t]{2}{*}{$2^{\text {nd }}$ quintile } & $0.070^{\star \star \star}$ & $-0.036^{\star \star \star}$ \\
\hline & $(0.020)$ & $(0.010)$ \\
\hline \multirow[t]{2}{*}{$3^{\text {rd }}$ quintile } & $0.161^{\star \star \star}$ & $-0.078^{\star \star \star}$ \\
\hline & $(0.023)$ & $(0.011)$ \\
\hline \multirow[t]{2}{*}{$4^{\text {th }}$ quintile } & $0.247^{\star \star \star}$ & $-0.134^{\star \star \star}$ \\
\hline & $(0.025)$ & $(0.012)$ \\
\hline \multirow[t]{2}{*}{ Richest quintile } & $0.356^{\star \star \star}$ & $-0.166^{\star \star \star}$ \\
\hline & $(0.030)$ & $(0.015)$ \\
\hline \multicolumn{3}{|l|}{ Ethnicity (Yoruba is base) } \\
\hline \multirow[t]{2}{*}{ Hausa } & $-0.152^{\star \star \star}$ & $0.095^{\star \star \star}$ \\
\hline & $(0.026)$ & $(0.012)$ \\
\hline \multirow[t]{2}{*}{ Fulani } & 0.046 & 0.019 \\
\hline & $(0.034)$ & $(0.016)$ \\
\hline \multirow[t]{2}{*}{ Igbo } & $0.256^{\star \star \star}$ & $-0.113^{\star \star \star}$ \\
\hline & $(0.024)$ & $(0.011)$ \\
\hline \multirow[t]{2}{*}{ Others } & $0.052^{\star *}$ & -0.008 \\
\hline & $(0.023)$ & $(0.011)$ \\
\hline \multicolumn{3}{|l|}{ Level of urbanization, night-time lights ( $\mathrm{DN}=0$ is base) } \\
\hline \multirow[t]{2}{*}{$\mathrm{DN}>0 \& \mathrm{DN} \leq 13$} & $0.042^{\star \star}$ & $-0.025^{\star \star}$ \\
\hline & $(0.021)$ & $(0.010)$ \\
\hline \multirow[t]{2}{*}{$\mathrm{DN}>13 \& \mathrm{DN} \leq 48$} & 0.038 & -0.018 \\
\hline & $(0.025)$ & $(0.012)$ \\
\hline \multirow[t]{2}{*}{$\mathrm{DN}>48$} & $0.123^{\star \star \star}$ & $-0.044^{\star \star \star}$ \\
\hline & $(0.031)$ & $(0.014)$ \\
\hline \multirow[t]{2}{*}{ Year dummy (2013) } & $-0.049 * \star \star$ & $-0.214^{\star \star \star}$ \\
\hline & $(0.007)$ & $(0.019)$ \\
\hline \multirow[t]{2}{*}{ Constant } & $-0.957^{\star \star \star}$ & 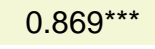 \\
\hline & $(0.001)$ & $(0.004)$ \\
\hline State-level fixed-effects? & Yes & Yes \\
\hline Observations & 31,993 & 31,993 \\
\hline
\end{tabular}

Source: Authors; Nigerian Demographic and Health Survey (NDHS), 2013 and 2008; and NOAA's National Geophysical Data Center. Notes: $\mathrm{DN}=$ digital number; values range from 0 to 63 . Standard errors are clustered at village level and given in parentheses. ${ }^{* \star \star} p<0.01$; ** $p<0.05 ;{ }^{*} p<0.10$. 
Table A2: Estimates of relationship between child height-for age z-score and stunting and the presence of same sex siblings born to monogamous women

\begin{tabular}{lcc} 
& $\begin{array}{c}\text { Height-for-Age } \\
\text { Z-score }\end{array}$ & Stunting rate \\
\hline Same sex & -0.013 & 0.013 \\
& $(0.013)$ & $(0.019)$ \\
\hline Additional controls & Yes & Yes \\
State-level fixed-effects? & Yes & Yes \\
Observations & 21,464 & 21,464 \\
\hline
\end{tabular}

Source: Authors; Nigerian Demographic and Health Survey (NDHS), 2013 and 2008; and NOAA's National Geophysical Data Center. Notes: Standard errors are clustered at village level and given in parentheses. ${ }^{\star \star \star} p<0.01 ;{ }^{* \star} p<0.05 ;{ }^{*} p<0.10$. 


\section{REFERENCES}

Akresh, R., J.J. Chenand, and C.T. Moore. 2016. "Altruism, Cooperation, and Efficiency: Agricultural Production in Polygynous Households." Economic Development and Cultural Change 64(4):661-696.

Altman, I., and J. Ginat. 1996. Polygamous Families in Contemporary Society. Cambridge, U.K.: Cambridge University Press.

Amare, M., C. Arndt, K.A. Abay, and T. Benson. Forthcoming. "Urbanization and Child Nutritional Outcomes." World Bank Economic Review.

Angrist, J.D. and W.N. Evans. 1998. "Children and Their Parents' Labor supply: Evidence from Exogenous Variation in Family Size." American Economic Review 88:450-477.

Arnold, F. 1992. "Sex Preference and Its Demographic and Health Implications." International Family Planning Perspectives, 18-93-101.

Arthi, V., and J. Fenske. 2016. "Intra-household Labor Allocation in Colonial Nigeria." Explorations in Economic History 60:69-92.

Arthi, V., and J. Fenske. 2018. "Polygamy and Child Mortality: Historical and Modern Evidence from Nigeria's Igbo." Review of Economics of the Household 16:97.

Basu, K. 2000. "On the Goals of Development." In Frontiers of Development Economics: The Future in Perspective, edited by G. M. Meier and J. E. Stiglitz, 61-86. Washington, D.C.: World Bank and Oxford University Press.

Becker, G. 1974. "A Theory of Marriage: Part II." Journal of Political Economy 82(2): S11-S26.

Behrman, J.R., and M.R. Rosenzweig. 2002. "Does Increasing Women's Schooling Raise the Schooling of the Next Generation?" American Economic Review 92(1):323-334.

Black, S.E., P.J. Devereux, and K.G. Salvanes. 2005. "The More the Merrier? The Effect of Family Size and Birth Order on Children's Education." Quarterly Journal of Economics 120(2):669-700.

Black, R.E., C.G. Victora, S.P. Walker, Z.A. Bhutta, P. Christian, M. de Onis, M. Ezzati, S. Grantham-McGregor, J. Katz, R. Martorell, R. Uauy, and the Maternal and Child Nutrition Study Group. 2013. "Maternal and Child Undernutrition and Overweight in Low-income and Middle-income Countries." The Lancet 382:427-451.

Boserup, E. 1970. Women's Role in Economic Development. London: George Allen and Unwin.

Briones Alonso, E., L. Cockx, and J. Swinnen. 2018. "Culture and Food Security." Global Food Security-Agriculture Policy Economics and Environment 17:113-127.

Caldwell, J.C., and P. Caldwell. 1987. "The Cultural Context of High Fertility in Sub-Saharan Africa." Population and Development Review 13(3):409-437.

Conley, D. 2000. "Sibship Sex Composition: Effects on Educational Attainment." Social Science Research 29(3): $441-57$.

Conley, D., and R. Glaube. 2006. "Parental Educational Investment and Children's Academic Risk: Estimates of the Impact of Sibship Size and Birth Order from Exogenous Variation in Fertility." The Journal of Human Resources 41(4):722-737.

Dahl, G.B., and E. Moretti. 2008. "The Demand for Sons." Review of Economic Studies 75:1085-1120.

Deschênes, O. 2007. "Estimating the Effects of Family Background on the Return to Schooling." Journal of Business \& Economic Statistics 25(3): 265-77.

Ezeh, A.C. 1997. "Polygyny and Reproductive Behavior in Sub-Saharan Africa: A Contextual Analysis." Demography 34 (3):355-368.

Fenske, J. 2015. "African Polygamy: Past and Present." Journal of Development Economics 117:58-73.

Gyimah, S.O. 2009. "Polygynous Marital Structure and Child Survivorship in Sub-Saharan Africa: Some Empirical Evidence from Ghana." Social Science \& Medicine 68(2):334-342.

Hadley, C. 2005. "Is Polygyny a Risk Factor for Poor Growth Performance among Tanzanian Agropastoralists?" American Journal of Physical Anthropology 126(4):471-480.

Headey, D. 2013. "Developmental Drivers of Nutritional Change: A cross-country analysis." World Development 42:76-88.

Henderson, J. V., A. Storeygard, and D.N. Weil. 2012. "Measuring Economic Growth from Outer Space." American Economic Review 102(2): 994-1028.

Hoddinott, J., J.A. Maluccio, J.R. Behrman, R. Flores, and R. Martorell. 2008. "Effect of a Nutrition Intervention During Early Childhood on Economic Productivity in Guatemalan Adults." Lancet 371:411-6.

Imhoff, M.L., W.T. Lawrence, D.C. Stutzer, and C.D. Elvidge. 1997. "A Technique for Using Composite DMSP/OLS City Lights Satellite Data to Map Urban Area." Remote Sens Environ 61(3): 361-370.

Jacoby, H.G. 1995. "The Economics of Polygyny in Sub-Saharan Africa: Female Productivity and the Demand for Wives in Côte d'Ivoire." Journal of Political Economy 103(5):938-971.

Jayachandran, S., and R. Pande. 2017. "Why are Indian Children Shorter than African children?" American Economic Review 107(9):2600-2629. 
Kaestner, R. 1997. "Are Brothers Really Better? Sibling Sex Composition and Educational Achievement Revisited." Journal of Human Resources 32(2):250-84.

Kugler, A.D., and S. Kumar. 2017. "Preference for Boys, Family Size, and Educational Attainment in India." Demography 54(3):835-59.

Le Strat, Y., C. Dubertret, and B. Le Foll. 2011. "Child Marriage in the United States and Its Association with Mental Health in Women." Pediatrics 128: 524-530.

Mammen, K. 2009. All for One or Each for Her Own: Do Polygamous Families Share and Share Alike? Working Paper. New York: Barnard College.

Milazzo, A. 2018. "Why Are Adult Women Missing? Son Preference and Maternal Survival in India." Journal of Development Economics 134:467-484.

Munro, A., B. Kebede, M. Tarazona-Gomez, and A. Verschoor. Forthcoming. "The Lion's Share: An Experimental Analysis of Polygamy in Northern Nigeria." Economic Development and Cultural Change.

Norling, J. 2018. "Measuring Heterogeneity in Preferences over the Sex of Children." Journal of Development Economics 135:199-221.

NPC (National Population Commission, Nigeria) and ICF International. 2014. Nigeria Demographic and Health Survey 2013. Abuja, Nigeria, and Rockville, Maryland, USA: NPC and ICF.

NPC (National Population Commission, Nigeria) and ICF Macro. 2009. Nigeria Demographic and Health Survey 2008. Abuja, Nigeria: NPC and ICF Macro.

Omariba, D., and M.H. Boyle. 2007. "Family Structure and Child Mortality in Sub-Saharan Africa: Cross-national Effects of Polygyny." Journal of Marriage and Family 69(2):528-543.

Pande, R.P. 2003. "Selective Gender Differences in Childhood Nutrition and Immunization in Rural India: The Role of Siblings." Demography 40(3):395-418.

Rahman, M. S., T. Howlader, M.S. Masud, and M.L. Rahman. 2016. "Association of Low-birth Weight with Malnutrition in Children under Five Years in Bangladesh: Do Mother's Education, Socio-economic Status, and Birth Interval Matter?" PLoS One 11(6): e0157814.

Rosenzweig, M.R., and K.I. Wolpin. 1980. "Testing the Quantity-Quality Fertility Model: The Use of Twins as a Natural Experiment." Econometrica 48(1): 227-240.

Rosenzweig, M.R., and K.I. Wolpin. 2000. "Natural "Natural Experiments" in Economics." Journal of Economic Literature 38(4):827-74.

Rosenzweig, M., and O. Zhang. 2009. "Do Population Control Policies Induce More Human Capital Investment? Twins, Birthweight, and China's "One Child" Policy." Review of Economic Studies 76:1149-1174.

Rossi, P., and L. Rouanet. 2015. "Gender Preferences in Africa: A Comparative Analysis of Fertility Choices." World Development 72: 326-345.

Rutstein, S.O., and K. Johnson. 2004. The DHS Wealth Index. Demographic and Health Survey (DHS) Comparative Reports no. 6. Calverton, Maryland: ORC Macro.

Sellen, D.W. 1999. "Polygyny and Child Growth in a Traditional Pastoral Society." Human Nature 10(4):329-71.

Smith, L.C, M.T. Ruel, and A. Ndiaye. 2005. "Why is Child Malnutrition Lower in Urban than in Rural Areas? Evidence from 36 Developing Countries." World Development 33:1285-1305.

Smith-Greenaway, E., and J. Trinitapoli. 2014. "Polygynous Contexts, Family Structure, and Infant Mortality in SubSaharan Africa." Demography 51(2): 341-366.

Storeygard, A. 2016. "Farther on Down the Road: Transport Costs, Trade and Urban Growth in Sub-Saharan Africa." Review of Economic Studies 83:1263-1295.

Strassmann, B.I. 2011. "Cooperation and Competition in a Cliff-Dwelling People." Proceedings of the National Academy of Sciences 108(2):10894-10901.

Sutton, P.C. 1997. "Modelling Population Density with Night-time Satellite Imagery and GIS. Computers." Environment, and Urban Systems 21(3-4):227-244.

Ukwuani, F.A., G.T. Cornwell, and C.M. Suchindran. 2002. "Polygyny and Child Survival in Nigeria: Age Dependent Effects." Journal of Population Research 19:155-171.

Wagner, N., and M. Rieger. 2015. "Polygyny and Child Growth: Evidence from Twenty-six African Countries." Feminist Economics 21(2):1-26.

Westoff, C. 2003. Trends in Marriage and Early Childbearing in Developing Countries. DHS Comparative Reports No. 5. Calverton, MD: ORC Macro.

WHO (World Health Organization). 2017. Nutrition in the WHO African Region. Brazzaville: WHO Regional Office for Africa.

WHO Multicentre Growth Reference Study Group. 2006. WHO Child Growth Standards: Length/Height-for-age, Weightfor-Age, Weight-for-Length, Weight-for-Height and Body Mass Index-for-Age: Methods and Development. Geneva: World Health Organization. 


\section{ABOUT THE AUTHORS}

Mulubrhan Amare is a Research Fellow with the Nigeria Strategy Support Program of the International Food Policy Research Institute (IFPRI) under the Development Strategy and Governance Division (DSGD) of IFPRI, based in Washington, DC. Channing Arndt is the Division Director of the Environment and Production Technology Division at IFPRI, based in Washington, DC. Kristi Mahrt is a Senior Research Analyst in EPTD of IFPRI, based in Colorado, USA. George Mavrotas at the time this research was done was a Senior Research Fellow in DSGD of IFPRI and Leader of IFPRI's Nigeria Strategy Support Program, based in Abuja. He is now based in the United Kingdom.

\section{ACKNOWLEDGMENTS}

The authors are grateful to James Fenske for valuable comments on previous versions of this manuscript. The usual disclaimer applies. 